\title{
Motivasi Ibu Tentang Toilet Training Pada Anak Usia I-3 Tahun Di Wilayah Kerja Posyandu Dahlia Puskesmas Campurejo Kota Kediri
}

\author{
(Mother Of Toilet Training Motivation In Children Ages 1-3 Years In The Working Area \\ Of Posyandu Dahlia Puskesmas Campurejo Kediri)
}

Hengky Irawan, Irma Dewi L

\begin{abstract}
Toilet Training on child constitutes an effort to see child to be able to controls deep poo and pee. So required by task for toilet training. Toilet Training is very important for the child's independence and psychological. So desperately needed readiness Mother, How the implementation and the role of mother in teaching Children Toilet Training. The purpose of this study was to determine maternal motivation in making toilet training in children aged 1-3 years in the working area of Dahlia IHC Health Center Campurejo Kediri.The design of this study using a descriptive design,this research in the working area of Dahlia IHC Health Center Campurejo Kediri.Its research subject is all Mother that have age child 1-3 years in IHC Dahlia June Dahlia 2011 as much 25 respondents (Total sampling). Collecting data with questionnaires and interviews. Its research variable is motivate mother in does toilet training. Data processing utilizes kualitatif's scale passes through editing, coding, tabulating, and scoring. so research measure is divided as tall motivation, motivation be and low motivation.Result respondenting to figure 6 respondents (24\%) having motivation less, 5 respondents (20\%) having motivation be and a considerable part which is 14 respondents $(56 \%)$ having tall motivation. So gets to be concluded by tall mother motivation to do toilet training caused total families deep child which more than one more make to have more experience ripe,mother work a large part housewife so mother time to do toilet training more intensive. The advice given is expected given the huge benefits to the mother and child about toilet training. Mother ought to applies toilet training on child and toilet training my mother taught to children early on.
\end{abstract}

\section{Keywords: motivation, Mother, Toilet Training}

\section{Pendahuluan}

Perkembangan anak secara umum terdiri dari beberapa tahap atau periode, salah satunya adalah periode kanak-kanak awal usia 1-3 Tahun (toddler), dimana periode ini terdapat perkembangan psikoseksual yaitu fase anal. Pada fase ini fungsi tubuh yang memberikan kepuasan berkisar antara sekitar anus. Tugas perkembangan yang harus dilalui anak adalah melakukan kontrol terhadap buang air besar atau buang air kecil. Toilet training merupakan salah satu usaha untuk melatih anak agar mampu mengontrol dalam proses eliminasi. Dalam melakukan latihan buang air kecil dan besar pada anak membutuhkan kesiapan pada diri anak dan keluarga baik secara fisik, psikologis, maupun secara intelektual, melalui persiapan tersebut diharapkan anak mampu mengontrol buang air besar dan buang air kecil sendiri (A,Alimul,2005)

Toilet training pada anak merupakan suatu usaha untuk melihat anak agar mampu mengontrol dalam melakukan BAB dan BAK. Sehingga diperlukan tugas untuk mengenalkan toilet training. Namun dalam toilet training kesiapan psikologis sangat lebih dibutuhkan oleh anak. Anak harus mampu mengenali dorongan untuk melepaskan atau menahan dan kemampuan untuk berkomunikasi pada ibunya. Pada saat itu anak harus bisa menguasai kemampuan motorik yang utama yaitu kebutuhan komunikasi (Nursalam,2005) 
Mengajari toilet training diperlukan stimulus yang sangat mirip dengan belajar membaca. Jika anak hidup di keluarga yang senang membaca, sering membaca secara alami dia akan menjadi anak yang suka membaca.Bila orang tua selalu BAK di toilet, biarkan anak mengalami proses karena ada anak yang cepat membaca dan ada yang lama sekali membaca (Sumardiono,2008)

Menurut Seto Mulyadi (8 september 2010) mengatakan selain secara medis.anak suka mengompol bisa disebabkan karena faktor psikologis. Anak yang stres, tertekan, tegang atau ketakutan, bisa terjangkit penyakit ngompol. Karenanya anak suka mengompol sebaiknya jangan dimarahi. : "Ini bisa jadi akan membuatnya ketakutan dan sering mengompol,"ujarnya

Menurut beberapa penelitian ditemukan anak usia 5 tahun, sekitar 23\% anak seringkali mengompol di tempat tidur, Pada usia 7 tahun sekitar $20 \%$ anak masih mengompol, Usia 10 tahun hanya $4 \%$ anak yang ngompol sedangkan pada usia remaja hanya sekitar 1-2\%. Masalah ini terjadi karena anak kebanyakan tidak mau menjalani toilet training sejak dini pada anak (Indonesia Medical Student Jornal.2010 diakses tanggal 5 November 2010).

Data lain menyebutkan ngompol terjadi pada anak laki-laki $60 \%$ dan anak perempuan $40 \%$ dan yang tak kalah penting, penyakit ngompol bisa disebabkan karena penyakit keturunan atau genetik (Zaki, 2010)

Dampak yang paling umum dalam kegagalan toilet training disebabkan oleh sikap orang tua yang lebih tidak tega pada anaknya atau kemalasan orang tua untuk melatih. Akibatnya walaupun anak telah berusia lebih dari 3 tahun anak tetap saja belum bisa BAK dan BAB di toilet,ngompol saat malam hari dan masih sering memakai popok serta perlakuan orang tua yang tidak rutin membiasakan anak ke kamar mandi (Andriana S Ginanjar, 2008)
Dalam Mengatasi masalah kegagalan toilet training diperlukan penanganan yang baik dari orang tua, kesabaran, dan kebijaksanaan sangatlah diperlukan oleh anak. Jika anak mengompol tetaplah bersikap tenang dan jangan memarahi, mempermalukan, atau menghukumnya. Berikan dukungan positif dan jalinan kerjasama serta kesabaran untuk menumbuhkan rasa percaya diri dan kemandirian anak (Suririnah, 2010)

Seorang Ibu hendaknya memberikan penghargaan kalau anak mampu menjalani toilet training, penghargaan dapat diberikan misalnya berupa,ciuman, belaian, pujian dan tepuk tangan karena penghargaan tersebut menimbulkan motivasi yang kuat pada diri anak untuk mengulang tingkah lakunya. Sedangkan menghukum harus disertai pengertian yang maksud dari hukuman tersebut bukan hukuman untuk melampiaskan kebencian dan kejengkelan terhadap anak sehingga anak tahu mana yang baik dan tidak baik. Dan dari penghargaan dan hukuman tersebut menimbulkan rasa percaya diri pada anak yang penting untuk perkembangan kepribadian anak.

Melihat fenomena di atas, maka peneliti tertarik untuk melakukan penelitian mengenai motivasi ibu dalam melakukan toilet training.

\section{Metode Penelitian}

Penelitian ini menggunakan desian deskriptif yang bertujuan menggambarkan motivasi Ibu tentang toilet training pada anak di Wilayah Kerja Posyandu Dahlia Puskesmas Campurejo Kota Kediri. Pada penelitian ini populasi yang diambil adalah seluruh ibu yang mempunyai anak usia toddler yang tercatat dalam buku register Posyandu Dahlia wilayah kerja Puskesmas Campurejo Kota Kediri sebanyak 25 orang anak. Dalam penelitian ini teknik sampel yang digunakan adalah total sampling. Variabel dalam penelitian ini adalah motivasi Ibu dalam melakukan 
toilet training. Analisa data menggunakan analisis deskriptif.

Hasil Penelitian

Data Umum

a) Karakteristik

\section{Berdasarkan Usia}

Responden

Tabel .1: Karakteristik umur Ibu yang memiliki anak usia 1-3 Tahun di Posyandu Dahlia Kelurahan Lirboyo Wilayah Kerja Puskesmas Campurejo Juni 2011 .

\begin{tabular}{lcc}
\hline \multicolumn{1}{c}{ Usia } & Jumlah & Persentase \\
\hline 20-25 Tahun & 4 & $16 \%$ \\
26-30 Tahun & 13 & $52 \%$ \\
31-35 Tahun & 4 & $16 \%$ \\
35-40 Tahun & 2 & $8 \%$ \\
>40 Tahun & 2 & $8 \%$ \\
\hline Jumlah Total & 25 & $100 \%$ \\
\hline
\end{tabular}

Berdasarkan Tabel 1 menunjukkan bahwa sebagian besar responden berusia 26-30 Tahun 13 responden (52\%), hampir setengahnya 31-35 Tahun 4 responden(16\%), dan sebagian kecil berusia $>40$ Tahun 2 responden $(8 \%)$

b) Karakteristik

Berdasarkan Pendidikan

Responden

Tabel 2 : Karakteristik Pendidikan Ibu yang memiliki anak usia 1-3 Tahun di Posyandu Dahlia Kelurahan Lirboyo Wilayah Kerja Puskesmas Campurejo Juni 2011.

\begin{tabular}{lcc}
\hline Jenis Pendidikan & Jumlah & Persentase \\
\hline SD & 3 & $12 \%$ \\
SLTP & 8 & $32 \%$ \\
SMA/SMEA & 10 & $40 \%$ \\
SARJANA & 4 & $16 \%$ \\
\hline Jumlah total & 25 & $100 \%$ \\
\hline
\end{tabular}

Berdasarkan Tabel 4.1.2 menujukkan hampir setengah responden berpendidikan SLTP sebanyak 8 responden(32\%), hampir setengahnya responden berpendidikan SMA/SMEA sebanyak 10 responden (40\%), sebagian kecil berpendidikan sarjana sebanyak 4 responden (16\%), sebagian kecil berpendidikan SD sebanyak 3 responden $(12 \%)$.

Pengetahuan Ibu mengenai toilet training apabila diukur melalui latar belakang Pendidikan melalui wawancara "Apa yang dimaksud dengan toilet training?" yang dinyatakan oleh responden adalah sebagai berikut :

Responden dengan Latar Pendidikan SD mengatakan:

"pipis ditatur"to mbak ( Wawancara tanggal 13 Juni 2011)

Responden dengan Pendidikan SLTP mengatakan;

"mengajarkan kepada anak untuk eek dan pipis (BAB dan BAK). (Wawancara tangggal 13 Juni 2011)

Beberapa Responden dengan lulusan SMA mengatakan:

"Tatur(toilet training) yang direncanakan pada anak". (Wawancara tangggal 13 Juni 2011)

Dan ditunjang oleh jawaban Responden yang berikut ini

" Anak dilatih untuk mengeluarkan kotoran di tempat yang benar"(Wawancara tanggal 13 Juni 2011)

Responden berpendidikan sarjana pun mengatakan:

"Latihan untuk bilang dan melakukan $B A B$ dan BAK di tempat yang seharusnya". (Wawancara tanggal 13 Juni 2011)

c) Karakteristik responden berdasarkan pekerjaan

Tabel.3 : Karakteristik Pekerjaan Ibu Posyandu Dahlia Kelurahan Lirboyo Wilayah Kerja Puskesmas Campurejo Juni 2011 .

\begin{tabular}{lcc}
\hline \multicolumn{1}{c}{ Pekerjaan } & Jumlah & Persentase \\
\hline IRT & 15 & $60 \%$ \\
PNS & 3 & $12 \%$ \\
Wiraswasta & 7 & $28 \%$ \\
\hline Jumlah & 25 & $100 \%$ \\
Total & & \\
\hline
\end{tabular}


Berdasarkan Tabel 4.1.3 dapat diketahui bahwa dari 25 responden sebagian besar sebagai ibu rumah tangga sebanyak $15(60 \%)$ responden.

d) Karakteristik Responden Berdasarkan Jumlah anak dalam keluarga

Tabel 4 : Karakteristik jumlah anak dalam keluarga di Posyandu Dahlia Kelurahan Lirboyo Wilayah Kerja Puskesmas Campurejo Juni 2011

\begin{tabular}{ccc}
\hline Jumlah Anak & Jumlah & Persentase \\
\hline 1 & 14 & $56 \%$ \\
2 & 7 & $28 \%$ \\
3 & 2 & $8 \%$ \\
$>3$ & 2 & $8 \%$ \\
\hline Jumlah Total & 25 & $100 \%$ \\
\hline
\end{tabular}

Berdasarkan Tabel 4 menunjukkan sebagian besar responden memiliki 1 anak 14 responden (56\%), hampir setengahnya memiliki 2 anak 7 responden (28\%), sebagian kecil memiliki 3 dan lebih dari 3 dengan jumlah yang sama masing-masing 2 responden (8\%)

e) Karakteristik responden berdasarkan Umur Anak

Tabel 5 : Karakteristik umur anak dalam keluarga di Posyandu Dahlia Kelurahan Lirboyo Wilayah Kerja Puskesmas Campurejo Juni 2011

\begin{tabular}{lcc}
\hline Umur Anak & Jumlah & Persentase \\
\hline 12-18 bulan & 7 & $28 \%$ \\
$19-24$ bulan & 8 & $32 \%$ \\
$25-36$ bulan & 10 & $40 \%$ \\
\hline Jumlah Total & 25 & $100 \%$ \\
\hline
\end{tabular}

Berdasarkan Tabel 5 menunjukkan hampir setengah responden memiliki anak berusia $25-36$ bulan 10 responden (40\%), hampir setengah responden memiliki anak berusia 19-25 bulan sebanyak 8 responden (32\%), hampir setengahnya memiliki anak berusia 12-18 bulan sebanyak 7 responden $(28 \%)$. f) Karakteristik responden berdasarkan jenis kelamin anak.

Tabel .6 : Karakteristik jenis kelamin anak di Posyandu Dahlia Kelurahan Lirboyo Wilayah Kerja Puskesmas Campurejo Juni 2011 .

\begin{tabular}{lcc}
\hline Jenis Kelamin & Jumlah & Persentase \\
\hline Laki-laki & 12 & $48 \%$ \\
Perempuan & 13 & $52 \%$ \\
\hline Jumlah Total & 25 & $100 \%$ \\
\hline
\end{tabular}

Berdasarkan Tabel 6 menunjukkan sebagian besar responden memiliki anak berjenis kelamin perempuan 13 responden (52\%), hampir setengahnya berjenis kelamin laki-laki 12 responden $(48 \%)$.

\section{Data Khusus}

a) Kesiapan Ibu dalam melakukan Toilet Training pada anak usia 1-3 tahun di Posyandu Dahlia Kelurahan Lirboyo Wilayah Kerja Puskesmas Campurejo Juni 2011.

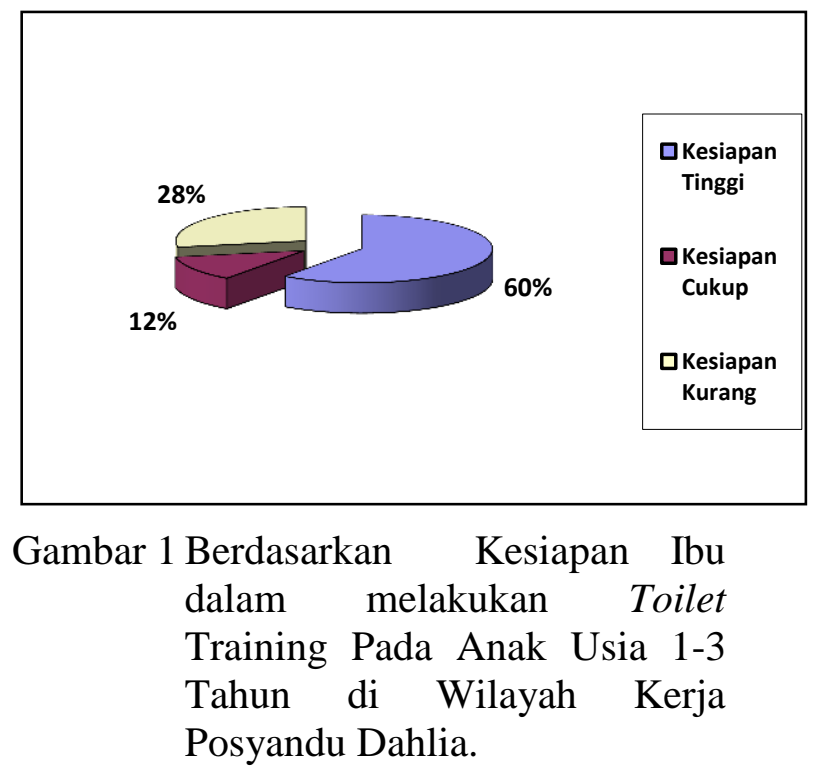

Berdasarkan pada gambar.1 Menunjukkan Kesiapan ibu dalam melakukan toilet training pada anak usia 1-3 Tahun di posyandu Dahlia sebagian besar memiliki kesiapan tinggi dalam toilet training 15 responden (60\%), hampir setengah memiliki kesiapan cukup dalam toilet training 7 responden $(28 \%)$ 
dan sebagian kecil memiliki kesiapan kurang dalam toilet training 3 responden $(12 \%)$.

Data melalui wawancara yang dilakukan oleh peneliti dengan pertanyaan "Mengapa Anak dilatih toilet training?" dan "Siapa yang mengajari toilet training pada anak?"

Beraneka ragam jawaban yang diperoleh peneliti kepada responden yang dikutip peneliti,responden pertama mengatakan:

"Anak dilatih mandiri dan agar tidak ngompol an dan biasanya yang melatih saya sendiri,bapak,dan neneknya pokoknya semua keluarga membantu ".(Wawancara tanggal 13 Juni 2011)

Responden kedua mengatakan:

"Supaya anak terbiasa BAB dan BAK di kamar mandi dan latihane dengan saya sendiri". (Wawancara tanggal 13 Juni 2011)

Responden ketiga mengatakan:

"dilatih tatur apik gawe anak mbak kaet mas mbek mbak e biyen mpun dibiasakan tatur biasanya kulo tatur $e$ sakben dalu sakderenge tilem dan shubuh injing ngoten nek anak mpun tangi.dadine ketiga anak kulo kaet umur 2 tahunan ngoten mpun mboten ngompol kaliyan eek ten sembarang tempat.dadose tetep bersih mbak anak kulo kaet dee cilik mergo mpun dikulinakne tatur e kaet umur 1 tahunan .saat tatur mboten kulo mawon ingkang nguruki tapi nggih bapak $e$ pokoke endi sing longgar waktu mbak".

(dilatih toilet training bagus untuk anak itu sendiri karena kebiasaan Ibu saat kakak-kakaknya dulu sudah di biasakan toilet training dan waktu toilet training Ibu membiasakan saat malam hari sebelum tidur dan setelah bangun pagi di pagi hari.jadi kebiasaan Ibu pada anaknya dalam toilet training membuat kebersihan anak terjaga semenjak anak berusia sekitar 2 tahun anak sudah berhasil menjalani toilet training. Yang melatih tidak hanya Ibu tapi juga bapak nya yang melonggarkan waktu dalam menjalani toilet training). (Wawancara tanggal 14 Juni 2011)

a) Cara Pelaksanaan Toilet Training pada anak usia 1-3 Tahun di Posyandu Dahlia Kelurahan Lirboyo Wilayah Kerja Puskesmas Campurejo Juni 2011

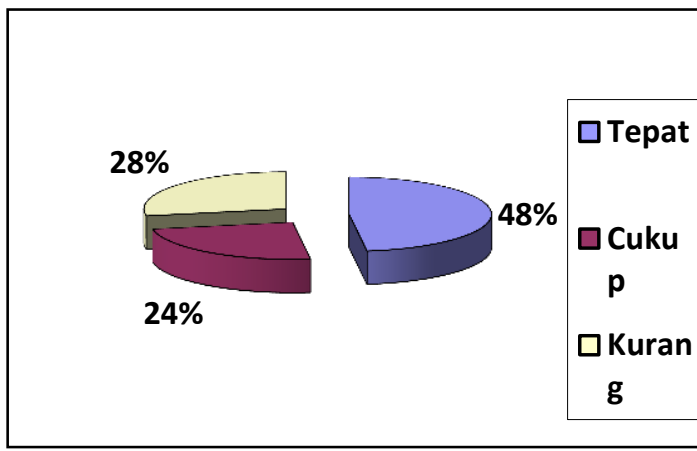

$\begin{array}{rlr}\text { Gambar .2 } & \text { Berdasarkan Cara } \\ & \text { pelaksanaan Toilet Training } \\ & \text { pada Anak Usia 1-3 Tahun di } \\ & \text { Posyandu Dahlia }\end{array}$

Berdasarkan pada gambar .2 menunjukkan Cara pelaksanaan toilet training pada anak usia 1-3 tahun di Posyandu Dahlia hampir setengah responden memiliki ketepatan tinggi dalam cara pelaksanaan toilet training 12 responden(48\%),hampir setengah memiliki ketepatan kurang dalam cara pelaksanaan toilet training 7 responden (28\%),dan sebagian kecil memiliki kesiapan cukup 6 responden( $24 \%)$.

Berdasarkan hasil wawancara dengan pertanyaan "Bagaimana cara melatih toilet training?" dan "Dimana anak dilatih toilet training?",

Responden mengatakan:"cara melatih pipise ya bangun tidur ndang di pipisne kalau anak mau pipis segera di ajak ke kamar mandi jadi kudu telaten mbak dan biasanya saya melatih e di kamar mandi".

(Cara melatih BAK sesudah bangun tidur harus segera di ajak ke kamar mandi jadi harus telaten atau rajin melatihnya ke 
kamar mandinya). (Wawancara tanggal 13 Juni 2011)

Responden lain mengungkapkan : "carane natur mbak,,biasa e di pangku kayak di bopong ngunu o lalu dibasahi kakinya sampai kencing dan kadang anak saya sampai keluar eek e (BAB) mbak". "Anu mbak biasa e saya latihe di WC atau kadang di selokan, licin soal nya kamar mandinya wedine jatuh ngunu”.

(Cara toilet training yang pertamatama anak di pangku atau di bopong lalu di rangsang dengan di basahi kakinya sampai anak mengeluarkan urine bahkan kadang keluar feses Ibu membiasakan nya biasanya di WC atau kadang di selokan dikarenakan licin lantainya kamar mandi dan agar anak tidak terpeleset ). (Wawancara tanggal 13 Juni 2011)

Responden berikutnya mengatakan:

"latihan melakukan mengajarkan BAK yang saya lakukan kalau anak saya tidur setiap jam 10 an saya usapkan di kelaminnya kapas basah jadi pipise(urine)langsung keluar kalau pagi setelah anak bangun tidur saya memberikan anak saya minum air putih 1 gelas lalu sebelum anak saya mandi saya jongkok kan dia di WC sambil saya pegangi anak juga bisa pipis sendiri mbak..mungkin karena minum air putih setelah bangun tidur jadi anak menjadi kebiasaan saat di WC anak bisa pipis(BAK) dan kadang BAB, saya seringnya membiasakan $B A B$ dan $B A K$ di WC atau kamar mandi tapi harus tetap memperhatikan keamanan mulai dari lampu kamar mandi yang terang agar anak saya tidak takut saat berada di kamar mandi"..(Wawancara tanggal 13 Juni 2011) b) Peranan Ibu dalam Toilet Training pada Anak Usia 1-3 Tahun di Posyandu Dahlia Kelurahan Lirboyo Wilayah Kerja Puskesmas Campurejo Juni 2011.

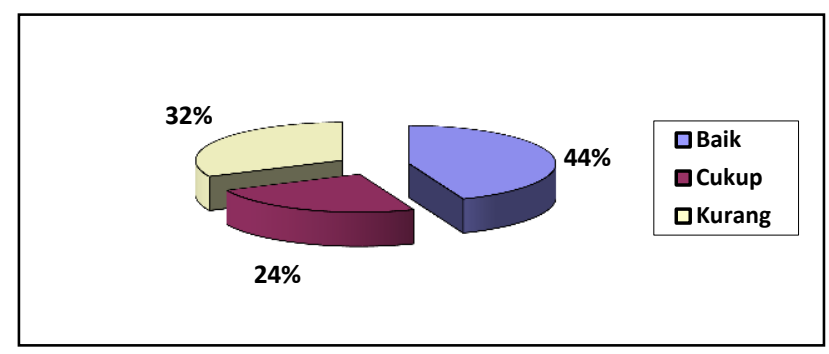

\section{Gambar 3 Berdasarkan Peranan Ibu dalam Toilet Training pada Anak Usia 1-3 Tahun di Wilayah Kerja Posyandu Dahlia}

Berdasarkan Pada gambar 3 menunjukkan Peranan Ibu dalam toilet training pada anak usia 1-3 tahun di Posyandu Dahlia hampir setengahnya memiliki peranan yang baik dalam toilet training 11 responden (44\%), hampir setengahnya memiliki peranan kurang dalam toilet training 8 responden (32\%), dan sebagian kecil memiliki peranan cukup dalam toilet training 6 responden (24\%).

Menurut hasil wawancara dengan pertanyaaan "Bilamana Anak gagal dalam melakukan toilet training, Apa yang anda lakukan?"

Beberapa responden mengatakan

Responden yang pertama:

"Anak saya kan masih kecil masih membutuhkan waktu dalam kerutinan agar tidak ngompol, dan saya tidak akan marah apalagi memukulnya bila anak saya tetap saja mengompol. (Wawancara tanggal 13 Juni 2011)

Responden yang kedua:

"Saya sebagai Ibu tidak nyerah mbak saya akan mencoba menarik perhatian anak saya misal saat anak di WC anak saya di kasih gayung dengan warna menarik atau memberikan mainan dalam bak kamar mandi agar anak semakin tertarik dalam tatur". (Wawancara tanggal 13 Juni 2011) 
Responden yang ketiga:

"Nek tetep ngompol kaliyan beol sembarangan mboten nopo-nopo mbak pancen dereng wancine, ya langsung kulo bersihne terus mengke anak e kulo resik $i$. gak opo-opo mbak pancen isih cilik ae mbesuk nek mpun ageng nek ngertos piyambak".

(Bila tetap ngompol dan buang air besar sembarangan tidak apa-apa memang belum saatnya. Kalau buang air kecil dan buang air besar langsung saya bersihkan dan si anak saya cebok i. tidak apa-apa memang anak masih kecil pada saat anak besar nanti pasti akan mengerti dengan sendirinya). (Wawancara tanggal 14 Juni 2011)

Namun dalam wawancara juga ada responden yang mengatakan

"kalau anak saya tetap aja mengompol ya saya seneni cubitii mbak biar ga kulino".

(Kalau anak saya tetap saja mengompol anak saya marahi dengan cara saya cubiti agar tidak menjadi kebiasaan buruk anak nantinya). (Wawancara tanggal 13 Juni 2011)

c) Motivasi Ibu tentang Toilet Training pada Anak Usia 1-3 Tahun di Posyandu Dahlia Kelurahan Lirboyo Wilayah Kerja Puskesmas Campurejo Juni 2011.

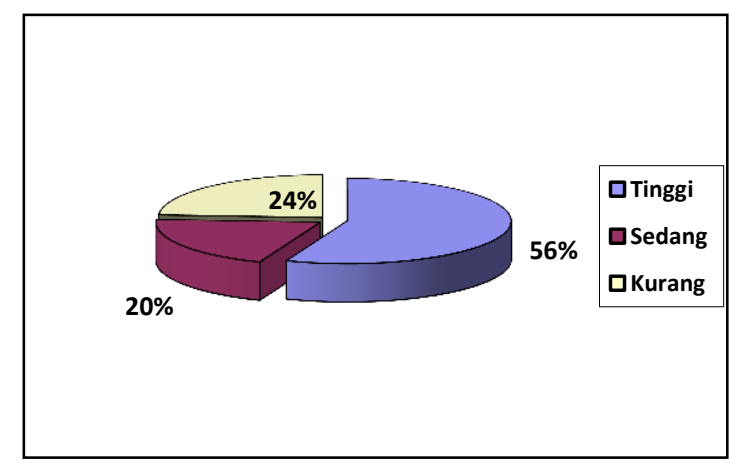

Gambar 4 : $\quad$ Motivasi Ibu dalam Melakukan Toilet Training pada anak usia 1-3 Tahun di Wilayah Kerja Posyandu Dahlia Puskesmas Campurejo Kota Kediri

Berdasarkan Pada Gambar 4.2.4 menunjukkan sebagian besar responden memiliki motivasi tinggi 14 responden (56\%) ,sebagian kecil memiliki motivasi kurang 6 responden(24\%), dan sebagian kecil memiliki motivasi sedang 5 responden $(20 \%)$.

Melalui hasil wawancara dengan Kader Posyandu Dahlia dengan peneliti "Bagaimana kondisi Ibu yang berada di lingkungan daerah sekitar Posyandu Dahlia mengenai toilet training pada anak usia 1-3 Tahun ?"

Kepala kader mengatakan "Ibu -ibu disini melakukan tatur mbak soalnya kalau dilihat dari segi ekonomi mungkin kan juga ibu rumah tangga jadi sayang kalau di buat beli pampers,lalu kalau dilihat dari segi lingkungan mungkin karena terbiasa dalam lingkup pondok pesantren jadi kebersihan dan menjaga kesucian rumah dari najis sangat diperhatikan oleh Ibu”. (Wawancara tanggal 13 Juni 2011)

\section{Pembahasan}

1. Kesiapan Ibu dalam melakukan toilet training pada anak usia 1-3 tahun di Wilayah Kerja Posyandu Dahlia Puskesmas Campurejo Kota Kediri

Berdasarkan Hasil penelitian kesiapan ibu dalam melakukan toilet training pada anak usia 1-3 Tahun di Posyandu Dahlia Wilayah Kerja Puskesmas Campurejo. sebagian besar memiliki kesiapan tinggi dalam toilet training 15 responden (60\%). Selain itu didukung oleh hasil wawancara pada sebagian besar responden menyatakan toilet training sangatlah bermanfaat pada anak terutama menjaga kebersihan dan kemandirian Anak. Pada hasil wawancara beberapa responden 
menyatakan dalam toilet training dibutuhkan kebiasaan dan kerutinan untuk melatihnya.

Menurut Robert C. Beck motivasi dapat diartikan sebagai tenaga penggerak yang mempengaruhi kesiapan untuk memulai melakukan serangkaian kegiatan dalam suatu perilaku. Motivasi tidak dapat diamati secara langsung, tetapi dapat diinterpretasikan dari tingkah lakunya. Motivasi dapat dipandang sebagai perubahan energi dari dalam diri seseorang yang ditandai munculnya feeling, dan didahului dengan tanggapan terhadap adanya tujuan. Pernyataan ini mengandung tiga pengertian, yaitu bahwa motivasi mengawali terjadinya perubahan energi pada diri sendiri individu, motivasi ditandai oleh adanya rasa (afeksi seseorang), motivasi dirangsang karena adanya tujuan (Sardiman A.M).

Sebagian besar responden di Posyandu Dahlia Wilayah Kerja Puskesmas Campurejo memiliki kesiapan tinggi melakukan toilet training, karena responden memperhitungkan tujuan dan manfaat dari toilet training yang bermanfaat bagi anak terutama dalam menjaga kebersihan dan melatih anak untuk mandiri. Dalam melewati toilet training anak dilatih, Komunikasi dengan Ibu dengan bahasa yang mudah dimengerti oleh anak, mengenal tandatanda bila ingin $\mathrm{BAB}$ dan $\mathrm{BAK}$, tempat yang benar untuk BAB atau BAK, serta mengenalkan anak untuk jongkok atau duduk di toilet. Kemampuan setiap anak dalam menjalani toilet training sangatlah berbeda-beda, terkadang bila ibu tidak siap dalam melatih toilet training anak akan mengalami kegagalan dalam menjalani latihan. Sehingga diperlukan kesiapan ibu yang tinggi untuk meluangkan waktu dan menemani anak dalam menjalani toilet training. Dan kesiapan itu akan muncul pada diri ibu bila ibu meyakini tujuan dan kebutuhan dari proses toilet training yang di jalani anak.
Faktor kedua yang mempengaruhi kesiapan ibu adalah pengalaman masa lalu responden. Pada penelitian hampir setengahnya memiliki anak lebih dari 1 sebesar 11 responden (44\%) dan pernah melakukan toilet training pada anak sebelumnya.

Pengalaman masa lalu mempengaruhi perilaku dan tindakan seseorang pada masa depan. Menurut Nursalam (2002) seseorang akan termotivasi karena adanya pengalaman masa lalu.

Pengalaman bagi responden yang sudah melakukan toilet training pada anak yang sebelumnya akan membuat responden memiliki mekanisme pertahanan yang baik, terutama dalam mendampingi anak dalam menjalani toilet training. Hal ini dikarenakan mereka mempunyai pengalaman dan mekanisme koping terhadap suatu streesor saat anak menjalani toilet training. Pengalaman masa lalu individu dengan anak sebelumnya akan mempengaruhi kesiapan individu tersebut, pengalaman akan membuat individu menjadi lebih siap dalam melakukan toilet training.

Kebutuhan muncul karena ada sesuatu yang kurang dirasakan oleh seseorang baik fisiologis dan psikologis, dorongan merupakan arah untuk memenuhi kebutuhan tadi, sedangkan tujuan merupakan akhir dari satu siklus (Luthan dalam Nursalam, 2003)

Perwujudan kasih sayang merupakan keinginan ibu untuk memenuhi kebutuhan anak sehingga anak tercukupi kebutuhan fisik dan psikologi nya. toilet training merupakan perwujudan kasih sayang ibu untuk memenuhi kebutuhan anak dalam bentuk fisik berupa kebersihan dan kesehatan anak sedangkan bentuk psikologi berupa kemandirian dalam tujuan akhir manfaat toilet training. Sehingga mendorong ibu untuk mewujudkan pemenuhan kebutuhan anak dengan mempersiapakan diri ibu dalam pelaksanaannya.

Tujuan motivasi menurut Ngalim Purwanto (2007) untuk menggerakan atau 
menggugah agar timbul keinginan dan kemauannya untuk melakukan sesuatu, sehingga dapat memperoleh hasil atau mencapai tujuan tertentu.

Kesiapan merupakan tolak ukur dalam pencapaian suatu tujuan dengan keinginan dan ketersediaan diri untuk melakukan sesuatu karena dengan kesiapan akan mempengaruhi hasil dalam pencapaian tujuan. Begitu pula dengan toilet training kesiapaan ibu sangat dibutuhkan dalam menentukan keberhasilan toilet training. Kesiapan ibu dapat dilihat dari kemauan ibu dalam meluangkan waktu dan kerjasama dengan si anak untuk menjalani toilet training.

\section{Cara pelaksanaan Toilet Training pada usia 1-3 tahun di Wilayah Kerja Posyandu Dahlia Puskesmas Campurejo Kota Kediri}

Berdasarkan penelitian didapatkan cara pelaksanaan toilet training pada anak usia 1-3 tahun di Posyandu Dahlia Wilayah Kerja Puskesmas Campurejo hampir setengah responden memiliki cara yang tepat dalam cara pelaksanaan toilet training 12 responden (48\%). Selain itu didukung dari hasil wawancara pada beberapa responden menyatakan cara melatih BAB dan BAK waktu yang sesuai saat bangun dan sebelum tidur.

Motivasi berhubungan erat dengan tingkah laku seseorang dan dapat diklasifikasikan sebagai berikut: (1) seseorang senang terhadap sesuatu apabila ia dapat mempertahankan rasa senangnya maka akan termotivasi melakukan kegiatan, dan (2) apabila seseorang merasa yakin mampu menghadapi tantangan maka biasanya orang tersebut terdorong melakukan kegiatan tersebut (Wahosumijo,1997).

Peneliti berpendapat tingkah laku merupakan salah satu rangkaian perwujutan cara untuk melakukan kegiatan, sehingga mendorong munculnya ide dan kreativitas ibu untuk menghadapi anak dalam menjalani toilet training. Keanekaragaman cara yang dilakukan oleh ibu dalam pelaksanaan toilet training baik dengan cara sederhana ataupun rumit. Hal itu merupakan bentuk upaya ibu dalam mendukung Keberhasilan anak dalam toilet training. Sehingga walaupun anak mengalami kesulitan dalam pelaksanaan toilet training ibu terus menerus memacu untuk melaksanakan toilet training kepada anaknya.

Teori penetapan tujuan mengemukakan bahwa penetapan suatu tujuan tidak hanya berpengaruh terhadap pekerjaan saja tetapi juga mempengaruhi orang tersebut untuk mencari cara efektif dalam mengerjakaanya. (Edwin Locke dalam mangkunegara,2005)

Keanekaragaman cara yang dilakukan ibu dalam melakukan toilet training pada anak yang didapat melalui hasil wawancara pada setiap responden memiliki cara yang berbeda-beda dalam melakukan toilet training. Walaupun $40 \%$ berpendidikan SMA dari 25 responden tidak mempengaruhi dalam cara ibu untuk mengajarkan toilet training. Hal ini disebabkan kemampuan responden untuk mengetahui keunikan sifat dan fisik anak menjalankan cara toilet training pada setiap anak berbeda-beda. Sehingga di butuhkan kerja keras dan usaha yang tepat baik melalui cara modifikasi yang menyenangkan, keefektifan waktu dan keintensifan cara pelaksanaan. Sehingga dalam toilet training anak tidak mengalami krisis ketakutan dan kecemasan. karena kemampuan ibu memberikan cara yang tepat dapat membantu anak mencapai keberhasilan toilet training tanpa melewatkan hal yang menyenangkan pada anak menjalani toilet training.

Menurut Mc. Clelland mengemukakan terdapat 3 motivasi sosial yang akan mempengaruhi perilaku manusia, salah satunya adalah kebutuhan untuk berprestasi dimana seseorang yang lebih dominan kebutuhan prestasinya, umumnya sangat peduli terhadap kualitas kerjanya. Sehingga mereka cenderung mengambil tanggung jawab dan senang 
mengerjakan tugas-tugas yang menantang. Sehingga cenderung mencari umpan balik untuk memperbaiki kualitasnya.

Cara pelaksanaan toilet training yang berbeda-beda merupakan bentuk cara ibu dalam kaitannya dengan motivasi sosial kebutuhan untuk berprestasi. Sehingga diperlukan cara ibu yang lebih efektif untuk melakukan kegiatan toilet training. Walaupun cara yang dipilih ibu terkadang rumit dan membutuhkan kerja keras hal tersebut bagi ibu bukanlah hambatan karena ibu akan bertanggung jawab atas cara yang ia pilih dan ibu akan selalu membenahi cara yang ia lakukan dalam toilet training agar si anak mampu menjalani training dengan mudah. Karena cara toilet training pada tiap anak sangatlah berbeda-beda. Kemampuan anak dalam menjalani toilet training dengan pemahaman dan pengertian akan memberi dampak yang berbeda karena keunikan anak .

Menurut Widayatun (1999) cara meningkatkan motivasi seseorang dapat berupa teknik tingkah laku (meniru, mencoba dan menerapkan) serta teknik intensif dengan cara mengambil kaidah yang ada.

Dalam toilet taining tidak hanya dibutuhkan cara ibu dalam proses pelaksanaan toilet training tapi juga cara ibu untuk mendorong anak agar termotivasi untuk meniru dan mempraktekan cara pelaksanaan toilet training. Salah satu cara dalam toilet training adalah mengajarkan cara duduk dan jongkok di toilet, dan menerapkan cara cebok yang benar. Hal tersebut sangat penting dilakukan oleh ibu untuk mengajarkan anak dalam toilet training pada anak.

Menurut Ngalim Purwanto (2007), fungsi motivasi dapat mendorong manusia untuk bertindak, menentukan arah perbuatan, menyeleksi perbuatan. Motivasi mampu menentukan perbuatan yang serasi dan mencegah penyelewengan guna mencapai tujuan.
Cara yang diterapkan oleh ibu dalam pelaksanaan toilet training pada anak yang beraneka ragam hendaknya ibu tetap menggunakan cara yang aman dengan tetap memperhatikan kondisi anak dan tetap fokus dari tujuan toilet training. Sehingga dibutuhkan cara yang benar dan sesuai dengan kondisi anak. Pilihan cara yang tepat akan memudahkan tercapainya tujuan dari toilet training itu sendiri.

\section{Peranan Ibu dalam toilet training pada anak 1-3 tahun di Wilayah Kerja Posyandu Dahlia Puskesmas Campurejo Kota Kediri}

Berdasarkan hasil penelitian menunjukkan peranan ibu dalam toilet training pada anak usia 1-3 tahun di Posyandu Dahlia hampir setengahnya memiliki peranan yang baik dalam toilet training 11 responden (44\%). Selain itu didukung hasil wawancara pada beberapa responden yang menyatakan bahwa responden tidak akan memperlakukan dengan kekerasan bila anak mengalami kegagalan dalam toilet training, karena kesadaran mereka bahwa anak memang belum mengerti dan masih membutuhkan waktu dalam menjalani toilet training.

Skinner mengemukakan suatu teori proses motivasi yang disebut operant conditing. Pembelajaran timbul sebagai akibat dari perilaku yang disebut modifikasi perilaku. Perilaku merupakan operant, yang dapat dikendalikan dan di ubah melalui penghargaan atau hukuman. Perilaku positif yang diinginkan harus dihargai dan diperkuat, karena penguatan akan memberikan motivasi peningkatan kekuatan tinggi dari suatu respon yang berakibat pengulangan.

Keberhasilan anak melakukan toilet training ditentukan oleh peranan ibu dalam bentuk perlakuan yang dapat dilihat dari pemberian penghargaan saat anak mampu dalam pelaksanaan. Bentuk peranan yang positif dapat membuat anak memacu dalam mengulangi tindakan oleh karena itu, diperlukan peran ibu untuk terus memberikan pujian. Bila dalam 
menjalani toilet training curahan kasih sayang dan perhatian tetap diberikan oleh ibu akan menambah rasa percaya diri anak dan anak akan terus belajar untuk keberhasilan toilet training, hal yang senada juga dapat terjadi bila Ibu memberikan hukuman saat anak mengalami kesalahan dalam toilet training, semakin sering anak dihukum akan menjadikan anak depresi dan anak akan cenderung ragu-ragu dalam menjalani toilet training yang berdampak kegagalan dalam toilet training .

Faktor lain yang dapat mendukung peranan Ibu dalam toilet training adalah kecukupan waktu dan kesempatan. Hal itu di dukung oleh pekerjaan Ibu yang sebagian besar sebagai IRT sebanyak $60 \%$ dari 25 responden.

Job Characterstic model menjelaskan bahwa motivasi yang tinggi dapat diraih melalui karakteristik dari pekerjaan itu sendiri, yang terdiri dari komponen identitas tugas, signifikasi tugas, variasi keahlian, otonomi, dan umpan balik. (Judge et all,2001)

Ibu rumah tangga memiliki peranan lebih besar dalam melatih anak dalam toilet training, dikarenakan lebih memiliki kesempatan dalam memberikan pola asuh dan kelonggaran waktu untuk mendampingi anak dalam BAB dan BAK secara teratur. Waktu dan kesempatan dalam menemani dan mengajari anak dengan perhatian intensif sangat dibutuhkan anak untuk kerutinan menjalani toilet training.

Menurut Sunaryo (2004) memotivasi dengan bujukan atau memberikan hadiah agar melakukan sesuatu sesuai harapan yang memberikan motivasi, selanjutnya memotivasi dengan identifikasi dengan menanamkan kesadaran sehingga individu berbuat sesuatu karena adanya keinginan yang timbul dari dalam dirinya sendiri dalam mencapai sesuatu.

Motivasi sangat mempengaruhi peranan Ibu dikarenakan dengan motivasi tinggi akan menanamkan rasa kesadaran bagi Ibu untuk berbuat sesuatu dalam mendampingi dan membujuk anak dalam menjalani proses toilet training. Dengan kesadaran dari dalam diri untuk ikut proaktif dalam melatih anak untuk berkemih akan mempercepat tujuan tercapainya toilet training.

Lingkungan memberi stimulus pada individu untuk berbuat sehingga dapat mempengaruhi perilaku manusia (Ngalim Purwanto, 1991). Menurut Nursalam (2003) faktor lingkungan mempengaruhi peran penting dalam motivasi. Faktor lingkungan meliputi komunikasi dan penghargaan terhadap usaha-usaha yang telah dilaksanakan.

Dilihat dari tempat penelitian peneliti berpendapat letak wilayah kerja posyandu Dahlia yang berada di Lingkungan Pondok Pesantren Lirboyo menjadi kan pengaruh lingkungan menjadi andil besar dalam cara pelaksanaan toilet training dikarenakan letak masjid, adanya ulama dan anjuran dalam menanamkan kesucian menjadi hal yang dianut dan dipatuhi oleh warga sekitar. Selain itu keberhasilan setiap ibu dapat mendorong ibu yang lain untuk mencapai keberhasilan yang sama dengan berbagi pengalaman dan cerita melalui interaksi mereka dalam masyarakat.

\section{Kesimpulan}

1. Kesiapan Ibu tentang Toilet Training pada anak usia 1-3 tahun di Wilayah Kerja Posyandu Dahlia Puskesmas Campurejo Kota Kediri.

Berdasarkan pada gambar 4.7 Menunjukkan Kesiapan ibu dalam melakukan toilet training pada anak usia 1-3 Tahun di posyandu Dahlia sebagian besar memiliki kesiapan tinggi dalam toilet training 15 responden (60\%), hampir setengah memiliki kesiapan cukup dalam toilet training 7 responden $(28 \%)$ dan sebagian kecil memiliki kesiapan kurang dalam toilet training 3 responden $(12 \%)$. 
2. Cara Pelaksanaan Ibu Tentang Toilet Training pada anak usia 1-3 tahun di Wilayah Kerja Posyandu Dahlia Puskesmas Campurejo Kota Kediri.

Berdasarkan pada gambar 4.8 menunjukkan Cara Pelaksanaan toilet training pada anak usia 1-3 tahun di Posyandu Dahlia hampir setengah responden memiliki ketepatan tinggi dalam cara pelaksanaan toilet training 12 responden (48\%), hampir setengah memiliki ketepatan kurang dalam cara pelaksanaan toilet training 7 responden (28\%), dan sebagian kecil memiliki kesiapan cukup 6 responden $(24 \%)$.

3. Peranan Ibu dalam Toilet Training pada anak usia 1-3 tahun di Wilayah Kerja Posyandu Dahlia Puskesmas Campurejo Kota Kediri.

Berdasarkan Pada gambar 4.9 menunjukkan Peranan Ibu dalam toilet training pada anak usia 1-3 tahun di Posyandu Dahlia hampir setengahnya memiliki peranan yang baik dalam toilet training 11 responden (44\%), hampir setengahnya memiliki peranan kurang dalam toilet training 8 responden $(32 \%)$, dan sebagian kecil memiliki peranan cukup dalam toilet training 6 responden $(24 \%)$.

\section{A. Saran}

Berdasarkan hasil kesimpulan maka peneliti memberi saran sebagai berikut:

\section{Bagi Instansi Kesehatan}

Dari hasil penelitian ini diharapkan bisa dipakai sebagai tambahan informasi dan pertimbangan bagi instansi kesehatan, untuk meningkatkan pengetahuan petugas kesehatan dalam memberikan informasi berupa penyuluhan untuk menerapkan dan meningkatkan motivasi ibu tentang toilet training pada anak 1-3 tahun.

\section{Bagi Responden}

Mengingat begitu besarnya manfaat bagi Ibu dan Anak mengenai toilet training, maka diharapkan agar Ibu menerapkan dan perwujudan nyata untuk melakukan toilet training pada anak 1-3 tahun dan mengajarkan toilet training pada anak sejak dini.

\section{Bagi Peneliti Selanjutnya}

Untuk memperoleh informasi yang jelas tentang motivasi ibu terhadap toilet training pada anak usia 1-3 tahun di wilayah kerja Posyandu Dahlia Puskesmas Campurejo Kota Kediri. Sehingga motivasi untuk menambah wawasan keperawatan serta penerapan ilmu yang didapat peneliti. Dan diharapkan melakukan penelitan selanjutnya yang lebih mendalam terkait dengan motivasi ibu tentang toilet training.

\section{Bagi Tempat Penelitian}

Dari hasil penelitian diharapkan Posyandu memberikan penyuluhan akan cara dan pentingnya toilet training dilakukan pada anak sejak dini untuk memberikan informasi mengenai toilet training yang lebih efektif.

\section{Daftar Pustaka}

Alimul, A. 2005. Pengantar Ilmu Keperawatan Anak 1. Jakarta: Salemba Medika.

Arikunto, Suharsimi. 1998. Prosedur Penelitian. Jakarta:Rineka Cipta.

Moersintowati, B. 2002. Tumbuh Kembang Anak Dan Remaja. Jakarta:Sagung Seto.

Nursalam. 2003. Konsep Dan Penerapan Metodelogi Ilmu Keperawatan. Jakarta: Salemba Medika.

Notoatmodjo, Sukidjo. 2005. Metodelogi Penelitian Kesehatan. Jakarta:Rineka Cipto.

Pariani, S, Nursalam. 2001. Riset Keperawatan Dan Teknik Penulisan Karya Ilmiah. Jakarta: Salemba Medika.

Soetjiningsih, 1998. Tumbuh Kembang Anak. Jakarta:EGC. 
Supartini, Yupi, 2004. Konsep Dasar Keperawatan Bayi Dan Anak. Jakarta: Salemba Medika.

Suherman, 2000. Buku Saku Perkembangan Anak. Jakarta:EGC.

Sugiyono, 2010. Buku Statistika Untuk Penelitian. Bandung : Alfabeta

Nursalam, 2005. Asuhan Keperawatan Bayi Dan Anak (untuk perawat dan bidan).Edisi pertama.Jakarta.Salemba Medika.

Soemanto, Wasty, 2006. Psikologi Pendidikan. Jakarta :Rineka Cipta

Notoatmodjo, Soekidjo. 2003. Ilmu Kesehatan Masyarakat. Jakarta: Rineka Cipta 